\title{
Combining legacy data with new drone and DGPS mapping to identify the provenance of Plio-Pleistocene fossils from Bolt's Farm, Cradle of Humankind (South Africa)
}

Tara R Edwards ${ }^{\text {Corresp., }}$ 1 ， Brian J Armstrong ${ }^{1}$, Jessie Birkett-Rees ${ }^{2}$ ， Alexander F Blackwood ${ }^{1}$ ， Andy I R Herries ${ }^{1,3}$, Paul Penzo-Kajewski ${ }^{1}$, Robyn Pickering ${ }^{4,5}$, Justin W Adams ${ }^{3,6}$

${ }^{1}$ The Australian Archaeomagnetism Laboratory, Department of Archaeology and History, La Trobe University, Melbourne, Victoria, Australia

2 Centre for Ancient Cultures, Faculty of Arts, Monash University, Clayton, Melbourne, Victoria, Australia

3 Centre for Anthropological Research, University of Johannesburg, Johannesburg, Gauteng, South Africa

4 Department of Geological Science, University of Cape Town, Cape Town, Western Cape, South Africa

5 Human Evolution Research Institute, University of Cape Town, Cape Town, Western Cape, South Africa

${ }^{6}$ Centre for Human Anatomy Education, Department of Anatomy \& Developmental Biology, Biomedical Discovery Institute, Faculty of Medicine, Nursing \& Health Sciences, Monash University, Clayton, Melbourne, Victoria, Australia

Corresponding Author: Tara R Edwards

Email address: T.Edwards@latrobe.edu.au

Bolt's Farm is a Plio-Pleistocene fossil site located within the southwestern corner of the UNESCO Hominid Fossil Sites of South Africa World Heritage Site. The site is a complex of active caves and more than 20 palaeokarst deposits or pits, many of which were exposed through the action of lime mining in the early $20^{\text {th }}$ Century. The pits represent heavily eroded cave systems, and as such associating the palaeocave sediments within and between the pits is difficult, especially as little geochronological data exists. These pits and the associated lime miner's rubble were first explored by palaeoanthropologists in the late 1930s, but as yet no hominin material has been recovered. The first systematic mapping was undertaken by Frank Peabody as part of the University of California Africa Expedition (UCAE) in 1947-1948. A redrawn version of the map was not published until 1991 by Basil Cooke and this has subsequently been used and modified by recent researchers. Renewed work in the 2000s used Cooke's map to try and relocate the original fossil deposits. However, Peabody's map does not include all the pits and caves, and thus in some cases this was successful, while in others previously sampled pits were inadvertently given new names. This was compounded by the fact that new fossil bearing deposits were discovered in this new phase, causing confusion in associating the 1940s fossils with the deposits from which they originated; as well as associating them with the recently excavated material. To address this, we have used a Geographic Information System (GIS) to compare Peabody's original map with subsequently published maps. This highlighted transcription errors between maps, most notably the location of Pit 23, an important palaeontological deposit given the recovery of well-preserved primate crania (Parapapio, 
Cercopithecoides) and partial skeletons of the extinct felid Dinofelis. We conducted the first drone and Differential Global Positioning System (DGPS) survey of Bolt's Farm. Using legacy data, high-resolution aerial imagery, accurate DGPS survey and GIS, we relocate the original fossil deposits and propose a definitive and transparent naming strategy for Bolt's Farm, based on the original UCAE Pit numbers. We provide datum points and a new comprehensive, georectified map to facilitate spatially accurate fossil collection for all future work. Additionally, we have collated recently published faunal data with historic fossil data to evaluate the biochronological potential of the various deposits. This suggests that the palaeocave deposits in different pits formed at different times with the occurrence of Equus in some pits implying ages of $<2.3 \mathrm{Ma}$, whereas more primitive metridiochoerine suids hint at a terminal Pliocene age for other deposits. This study highlights that Bolt's Farm contains rare South African terminal Pliocene fossil deposits and creates a framework for future studies of the deposits and previously excavated material. 


\section{COMBINING LEGACY DATA WITH NEW DRONE AND}

2 DGPS MAPPING TO IDENTIFY THE PROVENANCE OF

3 PLIO-PLEISTOCENE FOSSILS FROM BOLT'S FARM,

4 CRADLE OF HUMANKIND (SOUTH AFRICA)

5

6 Tara R. Edwards*1, Brian J. Armstrong1,, Jessie Birket-Rees ${ }^{2}$, Alexander F. Blackwood ${ }^{1}$,Andy

7 I.R. Herries ${ }^{1,3}$ Paul Penzo-Kajewski ${ }^{1}$, Robyn Pickering, ${ }^{4,5}$, Justin W. Adams ${ }^{3,6}$

8

1. The Australian Archaeomagnetism Laboratory, Department of Archaeology and History, La Trobe University, Bundoora, 3086, VIC, Australia

2. Centre for Ancient Cultures, Faculty of Arts, Monash University, Clayton, Melbourne, 3800, Australia

3. Centre for Anthropological Research, University of Johannesburg, Gauteng, South Africa

4. Department of Geological Science, University of Cape Town, Cape Town, South Africa

5. Human Evolution Research Institute, University of Cape Town, South Africa

6. Centre for Human Anatomy Education, Department of Anatomy \& Developmental Biology, Biomedical Discovery Institute, Faculty of Medicine, Nursing \& Health Sciences Monash University, Clayton, Melbourne, 3800, Australia

*Corresponding Author:

Tara R Edwards

Email address: T.Edwards@latrobe.edu.au

8 ABSTRACT 
29 Bolt's Farm is a Plio-Pleistocene fossil site located within the southwestern corner of the 30 UNESCO Hominid Fossil Sites of South Africa World Heritage Site. The site is a complex of active caves and more than 20 palaeokarst deposits or pits, many of which were exposed through

32 the action of lime mining in the early $20^{\text {th }}$ Century. The pits represent heavily eroded cave 33 systems, and as such associating the palaeocave sediments within and between the pits is 34 difficult, especially as little geochronological data exists. These pits and the associated lime miner's rubble were first explored by palaeoanthropologists in the late 1930s, but as yet no hominin material has been recovered. The first systematic mapping was undertaken by Frank Peabody as part of the University of California Africa Expedition (UCAE) in 1947-1948. A redrawn version of the map was not published until 1991 by Basil Cooke and this has subsequently been used and modified by recent researchers. Renewed work in the 2000s used Cooke's map to try and relocate the original fossil deposits. However, Peabody's map does not include all the pits and caves, and thus in some cases this was successful, while in others previously sampled pits were inadvertently given new names. This was compounded by the fact that new fossil bearing deposits were discovered in this new phase, causing confusion in associating the 1940s fossils with the deposits from which they originated; as well as associating them with the recently excavated material. To address this, we have used a Geographic Information System (GIS) to compare Peabody's original map with subsequently published maps. This highlighted transcription errors between maps, most notably the location of Pit 23 , an important palaeontological deposit given the recovery of well-preserved primate crania (Parapapio, Cercopithecoides) and partial skeletons of the extinct felid Dinofelis. We conducted the first drone and Differential Global Positioning System (DGPS) survey of Bolt's Farm. Using legacy data, high-resolution aerial imagery, accurate DGPS survey and GIS, we relocate the original fossil deposits and propose a definitive and transparent naming strategy for Bolt's Farm, based on the original UCAE Pit numbers. We provide datum points and a new comprehensive, georectified map to facilitate spatially accurate fossil collection for all future work. Additionally, we have collated recently published faunal data with historic fossil data to evaluate the biochronological potential of the various deposits. This suggests that the palaeocave deposits in different pits formed at different times with the occurrence of Equus in some pits implying ages of $<2.3 \mathrm{Ma}$, whereas more primitive metridiochoerine suids hint at a terminal Pliocene age for other deposits. This study highlights that Bolt's Farm contains rare South African terminal 
60 Pliocene fossil deposits and creates a framework for future studies of the deposits and previously

61 excavated material.

62

63

64

65

66

67

68

69

70

71

72

73

74

75

76

77

78

79

80

81

82

83

84

85

86 


\section{INTRODUCTION}

88 Bolt's Farm is the name given to a series of fossil bearing palaeocave remnants located $\sim 1.5-3.0$

$89 \mathrm{~km}$ to the southwest of the early Pleistocene early hominin (Paranthropus robustus, early Homo

90 and Australopithecus africanus) bearing sites of Swartkrans and Sterkfontein, and $\sim 1 \mathrm{~km}$ south

91 of the Rising Star Cave system (Homo naledi) (Berger et al., 2015; Dirks et al., 2015) (Fig. 1).

92 Apart from the little explored archaeological and fossil bearing site of Goldsmith's (Mokokwe,

93 2007) $0.5 \mathrm{~km}$ to the south, Bolt's Farm is the most southwesternfossil-bearing site in the Gauteng

94 exposures of the Malmani dolomite UNESCO Hominid Sites of South Africa World Heritage

95 Site (colloquially referred to as 'The Cradle'). The pits and caves that are now collectively

96 referred to as Bolt's Farm occur on three properties: the western Klinkerts property, the eastern

97 Greensleeves Property, and the northern Sterkfontein Quarry (Fig. 2). The fossil site is named

98 after Mr Billy Bolt, the owner of the original farm that sat on the eastern Greensleeves property

99 and Sterkfontein Quarry (known as Main Quarry). The western Klinkerts part of the site was

100 owned by the Clyde Trading Company (indicated on the original site map as the Amlors Ors Co.;

101 SOM SF1, SF2).

102

103

$<<$ Insert Figure 1 $>>$

104

105

As with the other caves in the area, Bolt's Farm was heavily mined for speleothem (calcium

106

carbonate from stalagmites, stalactites and flowstones) in the terminal 19th and early 20th

107

centuries. The speleothem was burnt in kilns to make lime for use in the gold extraction process.

108

Evidence for this is preserved as lime miner's cottages and kilns that survive at both the

109

northeast and southeastern end of the Greensleeves Property (Fig. 2). While discrete deposits

110

existed, mining revealed and created a series of pits and dumps from which fossils were collected

111 from the 1936 (Broom, 1937), to the current projects (Pickford \& Gommery, 2016).

112

113 The significance of Bolt's Farm lies both within this numerous, extensive network of pits that

114 have yielded a diverse range of faunal material (SOM Text S1) and the suggested Pliocene ages

115 for some of the specimens (Sénégas \& Avery, 1998; Gommery et al., 2008a). Early mentions

116 described Bolt's Farm as a single deposit (Cooke, 1963), while later work recognised the

117 inherent complexity and published faunal data relating to specific pits (e.g. Delson, 1984; Cooke, 
118 1991; 1993). It is now generally accepted that the site consists of deposits of various ages that

119 formed either as part of the same cave system at different times (Gommery et al., 2012), or may

120 represent the infill of several completely unconnected caves. Although several publications have

121 used biochronological correlations to suggest depositional ages for specific pits at Bolt's Farm

122 (e.g. Delson, 1984; Sénégas \& Avery 1998; Reynolds 2007; Gommery et al. 2008a), no

123 comprehensive review of the biochronologically sensitive taxa has been attempted. Recent

124 Cradle-wide dating suggests some cave localities may be younger than previously thought

125 (Pickering et al., 2018), which has particular impact on biochronological interpretations of some

126 Bolt's Farm pits forming within the earlier Pliocene (Sénégas \& Avery, 1998; Gommery et al.,

127 2008b).

129 While the use of spatial aids e.g. geographic information system (GIS), remote sensing and

130 photogrammetry for visualising landscapes has a strong history in archaeology (Gibbons 1991;

131 Lock \& Stancic 1995; Birkenfeld et al., 2015; de la Torre et al., 2015; Fernández-Lozano et al.,

132 2016; Jorayev et al., 2016; Dell'Unto et al., 2017) its application to palaeoanthropology and

133 palaeontology has previously been acknowledged as lagging (Conroy et al., 2008; Anemone et

134 al., 2011). These methods are wide reaching and can be applied on a landscape scale e.g.

135 mapping and identifying fossil bearing outcrops (Oheim 2007), mapping hominin migration

136 routes (Holmes 2007) and reconstructing palaeoenvironments (Bailey et al., 2011). GIS is also

137 extremely valuable on a intra-site scale, allowing not only for visualisation (Armstrong et al.,

138 2018) but analysis and reconstruction of bone and stone accumulations (Nigro et al., 2003).

139 While highly valuable these methods have yet to be applied to Bolt's Farm.

140

141 In this contribution, we chronicle the previous work carried out on the Bolt's Farm pits, from the

1421930 s to the present, with a particular focus on the names and locations of the various deposits

143 (Table 1). To this end, we provide new spatial data and make available accurate survey control

144 points for future use (SOM SF3). The aim of this is to reduce the confusion regarding pit location

145 and naming, which are the result not only of staggered research since the early 20th Century but

146 the intrinsically complex nature of the deposits across the surface at Bolt's Farm. We also

147 present an overview of the previously described and undescribed faunal material reposited across

148 US and South African institutions with the aim of providing key biochronological ages for the 
149 Bolt's Farm deposits where possible. In doing so we also provide the first basis for associating

150 historic and more recently developed fossil samples excavated from these pits, a critical step in

151 reconciling the faunal record from across this prolific locality and allowing for more justified

152 intra- and intersite faunal, taphonomic and palaeoecological analyses.

153

$<<$ Insert Figure 2>>

155

156

157

REVIEW OF PREVIOUS EXCAVATIONS, MAPPING AND NOMENCLATURE AT BOLT'S FARM

158 The first mentions of Bolt's Farm are by Broom (1937) but there is confusion as to the definite locality to which he is referring. Broom $(1937 ; 1939)$ used a number of site location names no longer used today: referring interchangeably to 'Sterkfontein Farm', 'Sterkfontein Caves', 'Bolt's Farm' and' Bolt's Workings at Sterkfontein'. In his initial publications, Broom (1937, 1939) described a number of novel carnivores Leptailurus spelaeus (Family Felidae, Order Carnivora; figured in Broom [1939] but specimen not currently locatable), Crossarchus transvaalensis (Family Herpestidae, Order Carnivora; figured in Broom [1939] but specimen not currently locatable), and the type specimen of the extinct hedgehog Atelerix major (Family Erinaceinae, Order Eulipotyphla; TM 1544; subsequently subsumed into Erinaceus (Atelerix) broomi per Werdelin \& Peigne, 2010). These specimens are described as originating from "Sterkfontein in a cave, about a mile south of that in which Australopithecus was found" (Broom, 1937 pp. 512), which fits the known location of what today is Bolt's Farm. Broom (1939) further qualifies the location of these specimens as "found at Bolt's workings on Sterkfontein" (Broom, 1939 pp. 333) alongside the description of the STS 130-299 specimen Machairodus transvaalensis (Family Felidae: Order Carnivora). Broom continued to sample at Bolt's Farm until 1948, describing additional type specimens such as Felis shawi (BF 1555;

174 Family Felidae, Order Carnivora; subsequently subsumed into Panthera leo Linnaeus 1758) and

175 Elephantulus antiquus (Family Macroscelididae, Order Macroscelidae; figured in Broom [1948]

176 but specimen not currently locatable), as well as preserved remains of Phacochoerus modestus

177 (BF3-3355; Family Suidae, Order Cetartiodactyla; subsequently subsumed into Phacochoerus antiquus) (Broom, 1948; Adams et al. 2015; see SOM). There has been considerable confusion over the provenance of these early fossil specimens to what is currently defined as Bolt's Farm, 
180 let alone specific pit deposits due to the ambiguity of these early reports that sadly likely cannot

181 be addressed short of direct specimen sampling (e.g. Trueman et al., 2005).

182

183 Between 1947 and 1948, the southern section of the University of California Africa Expedition 184 (UCAE) visited Bolt's Farm, led by C.L. Camp and F. E Peabody (Camp, 1948). Their aim was 185 to gain further fossil evidence and geological context for the australopithecine specimens 186 described by Dart (1925) and Broom (1936). The UCAE undertook systematic sampling of 187 fossiliferous calcified deposits across the Cradle, including from several miners pits and rubble on Bolt's Farm. While members of the UCAE did keep detailed field dairies recording daily activities and discoveries, it is often difficult to reconcile whether specimens were identified in situ or collected from miner's rubble. Further, some localities have several rubble dumps nearby and subsequently it can be difficult to associate a rubble dump with any one pit. Attention was often paid to the matrix adhering to any specimens collected, and attempts made to match this with sediment in a nearby locality. Frank Peabody created the first known map of the site (SOM SF1 SF2; list of pits Table 1), which was not published in its original form until recently (Monson et al. 2015) - although used by Cooke (1991) to generate his map (see below). The expedition amassed a significant collection of fossils from a range of sites, now housed at the University of California Museum of Paleontology (UCMP) (Peabody, 1954; Monson et al., 2015), with some specimens repatriated to Evolutionary Studies Institute at the University of the Witwatersrand (Johannesburg) and the Ditsong National Museum of Natural History (Pretoria), South Africa.

201

Due to his sudden death in 1958, Peabody was unable to prepare a detailed report of his work at Bolt's Farm, as he had done for Taung (Peabody, 1954). Subsequently, Cooke visited the UCMP in 1957-1958 (as well as in 1975 and 1983) to study the fossils recovered by the expedition (Cooke, 1991). Cooke (1991 p.9) published a map "redrawn directly" from Peabody's survey map, including pit numbers, associated names and locality numbers from the UCAE (Pits 1-16 and 23-25). 
211 fossil dumps and attempted to relocate all sites from the UCAE using Cooke's 1991 map

212 (Sénégas et al., 2002). While they were not able to identify all the sites with certainty, the project

213 did discover a new site, Waypoint 160 (Sénégas \& Avery, 1998), and microfauna from the

214 deposits has been used to argue a terminal Miocene or earlier Pliocene age for the deposits (5-4

215 Ma, Sénégas \& Avery, 1998; 5.4-5 Ma, Gommery et al., 2008a).

216

217 The HOPE (Human Origins and Past Environments) project, a collaboration of French and South

218 African researchers based out of the Ditsong National Museum of Natural History, worked at the

219 site from 2001. They attempted to align the UCAE 'loci' on Cooke's (1991) map with those

220 observed in the field (Sénégas et al., 2002; Thackeray et al., 2008). From 2006 HOPE

221 transformed into the HRU (HOPE Research Unit), conducting regular survey and excavations at

222 Bolt's Farm. As a result, several previously undiscovered sites were described (Gommery et al.,

223 2012). In order to expose the bone rich in situ breccias, detailed excavation of several unstudied

224 deposits (Pit 14, Brad Pit A \& B, Milo A \& B) were undertaken. An updated map was presented

225 in Thackeray et al., (2008), which included the re-identified deposits from Sénégas et al., (2002)

226 and used names rather than the original UCAE Pit numbers: Pit 7 renamed Bridge Cave, Pit 11

227 renamed X Cave, Pit 14 (incorrectly listed as Pit 15) is renamed Aves Cave and Pit 3 renamed

228 Cobra Cave. Locations for other UCAE Pits, such as Pit 2 (renamed H Cave), Pit 1, Pit 8 (named

229 Rodent Cave) are also suggested. Thackeray et al. (2008) also map a number of 'new' sites in

230 addition to Waypoint 160 and Alcelaphine Cave, including Dom's Site, Machine Cave, X Cave

231 and Y Cave.

232

233 Gommery et al., (2012) built on this research when describing another series of 'new' sites,

234 including a sequence north of Pit 23 called Brad Pit A-C, a series west of Pit 6 called Milo's Pit

235 A and B, Brigitte Bones A and B, and Carnivore Pit. Further to the northwest another new

236 locality is designated Franky's Cave (Gommery et al. 2012). Gommery et al., (2014) present a

237 simplified map of the Klinkerts property pits (excluding new localities Brigitte Bones, Dom's

238 and Brad Pit C).

239

240 Monson et al., (2015) attempted to clarify issues around the naming of pits through a historical

241 summary, along with the accession of taxa from the previously unreported New Cave and Jackal 
242 Cave. While the authors included a summary table with alternative names for the original pits

243 recorded in 1947, sites since discovered or with material not accessioned at UCMP (e.g.

244 Waypoint 160) were not included.

245

246 The history of staggered research at Bolt's Farm spanning eight decades has created a number of

247 issues regarding the consistency of naming practices across the site, with some pits acquiring two

248 names, or being 'double discovered'. This paper aims to provide clarity and rectify these issues

249 of misidentification. Our intent is to create a transparent scheme, advocating for a return to the

250 original naming practices of the site initiated by Camp and Peabody, while also producing a new

251 georectified map to assist in ongoing research at the site (Fig. 2).

$252<<$ Insert Table 1 >>

253

$254<<$ Insert Table 2>>

255 METHODS

256 Field work was undertaken as part of South African Heritage Resource Agency Permit ID 866, Ref

257 No. 9/2/233/0032.

258

259 Aerial imagery, site survey and GIS

260 High-resolution aerial imagery was obtained using an eBee senseFly drone. Imagery was

261 processed using Agisoft PhotoScan Pro 1.16 and Georectified on to the South African

262 Coordinate System (Hartebeesthoek 94/ Lo27, EPSG:2052, SA 2010 GEOID), and later

263 converted to World Geodetic System (WGS) 84 Universal Transverse Mercator (UTM) Zone

$26435 \mathrm{~S}$ for convenience. Survey control points were established at twelve locations across the site

265 (SOM F3). These were then exploited for a feature based foot survey of the landscape using a

266 Leica GPS1200+ Differential Global Positioning System (DGPS), which enabled sub-centimetre

267 accuracy of surveying positions. This recorded the location of all pits, caves, trenches, historical

268 structures and geological outcrops. DGPS survey was processed with Leica Geo Office and

269 exported to ascii format. Both the Aerial imagery and survey data were imported into ESRI

270 software, ArcMap and ArcScene 10.4. Historical imagery (Peabody's map and the later maps of

271 (Cooke, 1991; Sénégas et al., 2002; Thackeray et al., 2008; Gommery et al., 2012) were 
272 georectified on to the aerial imagery, allowing for a direct comparison between our new data and 273 the previous maps (Fig. 3). The raw DGPS data (converted to UTM 35s) has been provided, in

274 addition to drone aerial imagery, and our new georectified site map, made available via figshare.

275

276 Faunal analysis

277 The Bolt's Farm faunas are curated across three international institutions. The University of 278 California Expedition sample is now curated at the University of California Museum of 279 Paleontology (UCMP) at the University of California, Berkeley (Cooke, 1991, 1993; Monson et 280 al., 2015). Decades of intermittent processing and cataloguing has produced a substantial sample 281 across most of the pits across the Bolt's Farm complex. Direct evaluation of specimens to establish 282 primary identification were made in reference to the extensive body of published descriptions of 283 the UCMP and larger South African record, an extensive database of measurements, photographs, 284 and notes on South African fossils and an unpublished summative manuscript on the UCMP 285 collections provided by HBS Cooke (Cooke, pers. comm. 2008). These collections were studied 286 directly by one of us (JWA) during two data collection periods in 2007 and 2012 in collaboration with Dr. Alan Shabel (Department of Integrative Biology, UC Berkeley).

Two South African institutions (Evolutionary Studies Institute, University of the Witwatersrand, Johannesburg; Ditsong National Museum of Natural History, Pretoria) are repositories for some Bolt's Farm specimens and have been regularly studied by JWA over the course of the last 15 years, and were evaluated specifically for this study during field seasons in 2015-2017. Fossils described from recent excavations at Bolt's Farm (e.g. those conducted since the UCAE) were not available for direct study, and any reference to these fossils in our review of the biochronologically relevant taxa comes from published literature - with the exception of the Milo's A suids which were examined earlier (Gommery et al., 2012).

\section{RESULTS}

\section{Combining legacy maps and accurate spatial data}

300 Table 1 shows the Peabody map localities and associated modern pit names and new DGPS coordinates for known locations. Note that some pits from 1947 have now been re-identified but were listed as 'new discoveries' by subsequent publications (Sénégas et al., 2002; Thackeray et 
303 al., 2008; Gommery et al., 2012). Table 2 presents a list of new locales, from work conducted

304 between 1996-2016 which have published fauna associated with the deposits (Sénégas \& Avery,

305 1998; Sénégas, 2000; Sénégas et al., 2002; Thackeray et al., 2008; Gommery et al., 2012;

306 2014;2016; Pickford \& Gommery, 2016).

307

308 Accurate locations of all pits across the Klinkerts and Greensleeves properties are presented in

309 Fig. 2. These data have been overlain with a georectified version of Peabody's original map,

310 Cooke (1991)'s interpretation of this map, and subsequent publications which relocated pits and

311 announced new localities; Sénégas et al., (2002), Thackeray et al., (2008) and Gommery et al.,

312 (2012) with discrepancies and clarification of complicated areas shown in Fig. 3.

313

314 Importing and georectifying Peabody's original map with our DGPS data and published maps

315 from 1991- 2012 identifies discrepancies in four areas (Table 1; Fig. 3 A-D). Three of these

316 relate to ambiguity in the first published map (Cooke 1991), from which all subsequent maps

317 until now were produced. Firstly, the precise locations of Pits 5 and 13-15 are not easily

318 discernible (Fig. 3A). The location of Pit 11 is correctly identified by Cooke (1991) (Fig. 3B).

319 The designation of Pit 23 is placed between two localities whereas Peabody labels Pit 23 as the

320 more easterly of the two pits (Fig. 3C). Through georectification of the original map and archival

321 research (SOM SF2, SF3) we have determined Pit 23 to be the more easterly of the two pits,

322 however it has been continually misidentified in the literature. The location of Pit 16 is cut off

323 the map, allowing for this to be re-discovered as a new site more than twenty years later (Fig.

324 3D). Without direct comparison with the original Peabody map it is impossible to interpret these

325 complex areas on Cooke's map.

326

327 Sénégas et al., (2002) published a map following the Cooke (1991) version along with GPS

328 coordinates for Pits 3-7, 9, 11-15 and 23 (Table 1). This new map features 'Breccia outcrop' from

329 Cooke's (1991) map and 'new' locations Waypoint 160, Alcelaphine site and the Femur Dump

330 (Sénégas et al., 2002; Gommery et al., 2008b). While the latter is present as 'Tit Hill' on

331 Peabody's map, it was not copied over by Cooke (1991) and ambiguity in this region led to

332 misidentification of Pit 23 (Fig. 3B). Most of the locations reported in Sénégas et al., (2002) plot

333 close to identifiable pits on new aerial imagery, with a few exceptions. Firstly, 'Breccia outcrop' 
334 plots directly adjacent to Pit 6, making it possible that a breccia dump was mistakenly logged as 335 an outcrop. Digital comparison of both maps (Cooke, 1991; Sénégas et al., 2002) show that the

336 'Breccia outcrop' locations do not correlate spatially. There was uncertainty regarding which

337 deposit represented Pit 12, resulting in the creation of Pit 12A and 12B. Moreover, the location

338 for Pits 5 and 13, while being associated with a pit on aerial imagery is not where the original

339 Pits 5, 13 and 14 are located (Fig. 3A). Archival research of original field notebooks at the

340 UCMP showed Pit 13 to be a dump associated with Pits 5 and 14 (SOM SF5), which is not clear

341 from looking at either the Peabody or Cooke (1991) map.

342

343 Thackeray et al., (2008) present an overview of research at Bolt's Farm and include an updated

344 map with several new localities along with GPS coordinates. Plotting these coordinates on

345 georectified aerial image shows several inconsistencies with the original mapped pits (Fig. 3).

346 While Pit 14 was correctly identified as Benchmark Pit, coordinates given match those at Pit 8

347 (Fig. 3A). Pit 5 was placed more than $20 \mathrm{~m}$ away from the original mapped pit. They map in a pit

348 which is identified as Pit 13 and given the name Arm Pit; however, as stated above, archival

349 research reveals Pit 13 was a dump. Ultimately, Arm Pit does correspond to a real world location

350 and moving forward should continue with this name without the designation of Pit 13 (Fig. 3A).

351 GPS coordinates show that Pit 11 is incorrectly identified as a new site, X Cave while U Cave

352 located to the south is labelled Pit 11 (Fig. 3B). Following Cooke (1991)'s map and Sénégas et

353 al., (2002) Pit 23 is incorrectly identified (Fig. 3C).

355 Gommery et al., (2012) present nine newly discovered localities with GPS coordinates. While 356 many of the discoveries are legitimate with coordinates that plot close to identifiable pits (Brad

357 Pit A-C, Alcelaphine Site, Dom's Cave) others are misidentifications of old sites or there are 358 issues with the coordinates. Several misidentifications continue through the literature including 359 Pit 11, Pit 23, Pit 14 and Pit 5 (Fig. 3). The new sites Milo A and Milo B correspond to localities 360 mapped by the UCAE in 1947: 'Bushman outcrop' and Pit 16 respectively (Fig. 3D). Using both 361 supplied coordinates and overlaying our georectified map, we were unable to align Brigitte

362 Bones A or B with any identifiable pits (Fig. 3D).

364 Some of the issues raised here were addressed by Pickford \& Gommery (2016) who used, but 
365 did not publish in full, Peabody's original map. Access to this allowed them to identify and 366 correct many errors made especially in the area they have called the "Aves Cave Complex".

367 However, while Pits 8, 14 and 15 are correctly identified Pit 5 is incorrectly labelled Pit 13.

368 Direct comparison with the map published in Pickford \& Gommery (2016) was not possible due 369 to small size of their map, which limited accurate georectification.

370

371 Biochonologically Significant Bolt's Farm Fauna

372 A full description of the biochronologically-informative faunas from the Bolt's Farm localities

373 described to date is provided in full in our SOM (Text S1) and the summed results of our

374 evaluation are presented in Table 3. We wish to emphasise that the faunal data and descriptions

375 provided here and within supplementary online material, while reflecting a substantial advance

376 over prior taxon-focused or summative publications on the Bolt's Farm fossil faunas, is only

377 inclusive of specimens broadly relevant for establishing biochronological interpretations of the

378 pit deposits. The descriptions and discussion should not be taken as a comprehensive description

379 or listing of taxa from these deposits across these institutions.

380

381 There is insufficient faunal data from Pits 2, 8, 15, 17, Jackal Cave and Brad Pit A and B to

382 establish a biochronological age bracket for these deposits. The majority of the described Bolt's

383 Farm localities were deposited after 2.33 Ma given the regular recovery of Equus specimens that

384 must postdate the entry of the genus into Africa (Table 3; Geraads et al., 2004). A probable

385 minimum depositional age boundary of 0.78 Ma can be established for Pits 1,3 , and 25 by the

386 occurrence of the extinct bovid Antidorcas recki, which disappears from South African deposits

387 after the formation of Elandsfontein (Klein et al., 2007; Braun et al., 2013). Pit 16 contains

388 extinct three-toed horse (Eurygnathohippus) and was likely deposited prior to $0.99 \mathrm{Ma}$ (SOM

389 Text S1). Pits 4, 5, and New Cave lack fauna that can restrict the minimum depositional age.

390

391 Only the Pits 7, 10, 14, 23, Waypoint 160 and Milo's A deposits contain faunal specimens that

392 may have been deposited prior to 2.33 Ma. The recovery of an extinct elephant (Elephas) from

393 Pit 7 suggests a maximal depositional age of 4.4-2.5 Ma (potentially extending to 2.0 Ma; SOM

394 Text S1); however, as noted above the provenance of the specimen within the deposits is

395 unknown and a recent $\mathrm{U}-\mathrm{Pb}$ age indicates some flowstones in the cave formed $<\sim 1.8 \mathrm{Ma}$ 
396 (Pickering et al., 2018). As such, an in depth study of the Pit 7 stratigraphy and potential

397 associations of the specimen will be necessary to to establish a robust chronology for this

398 location. The Pit 10 deposits contain the type specimen of the herpestid Ictonyx bolti

399 (subsequently subsumed into Prepoecilogale bolti [Cooke 1985]) known only to occur in the

400 late Pliocene ( 3.7-2.5 Ma) from northern and eastern African deposits (SOM Text S1). The Pit

401 14, 23 and Milo's A deposits all contain Stage I Metridiochoerus andrewsi craniodental remains

402 that are morphologically analogous to those recovered from the Makapansgat Member 3 deposits

403 (3.03-2.58 Ma) (Partridge, 1973; Herries, 2003; Herries et al., 2009; Herries et al., 2013). This

404 may reflect a similar maximal depositional age; however, the limits of the South African suid

405 record mean that at present we can only infer deposition of these specimens prior to $1.95 \mathrm{Ma}$

406 (SOM Text S1). Finally, although Waypoint 160 has been previously suggested to date to after

407 the Langebaanweg E Quarry deposits ( 5.2 Ma; Roberts et al., 2011) and prior to the

408 Makapansgat Member 3 deposits (3.03-2.58 Ma), as noted above and in SOM Text S1, without

409 an established FAD or LAD for Euryotomys bolti and the recent identification of Panthera cf.

410 leo, such a Pliocene age is not clearly supported by the fauna. Equally, recent $\mathrm{U}-\mathrm{Pb}$ ages suggest

411 flowstones in the cave formed at $<\sim 2.3 \mathrm{Ma}$, supporting the notion that at least some of this

412 deposit is Early Pleistocene (Pickering et al., 2018).

413

414 DISCUSSION

415 The extensive history of research at Bolt's Farm has yielded a substantial and diverse faunal 416 sample from the known localities. The palaeontological significance of Bolt's Farm has lagged

417 behind that of other South African deposits due to the divided curation of materials from across

418 the deposits, the sporadic history of excavation, and confusion over location and nomenclature of 419 specific pits.

420

421 The combination of several different teams working at Bolt's Farm through the decades, often 422 with significant time between excavations and collections, and the disturbance of many of the 423 deposits by lime mining has cumulatively lead to the present situation of multiple names for 424 individual deposits and ambiguity as to the exact location of a number of the pits. While attempts 425 have been made to reconcile disparity between the naming of deposits and faunal assemblages 426 (Monson et al., 2015) and to build new naming strategies for the pits (Pickford \& Gommery., 
427 2016), the lack of an overarching approach focused on the accurate spatial identification of 428 original and recently discovered pits has only added to the confusion.

429

430 By digitally overlaying Peabody's original map (Monson et al., 2015) and subsequently 431 published maps (Cooke, 1991; Sénégas et al., 2002; Gommery et al., 2012) with new aerial 432 imagery and survey data, we are able to recognise pit misidentifications and errors with naming 433 (Fig. 3). Spatially accurate mapping of palaeontological sites is crucial for ongoing work, 434 especially palaeomagnetic and Uranium-Lead (U-Pb) dating, which both require secure 435 stratigraphic contexts. In addition, the provision of 3D surveying benchmarks across the site 436 means that all future fossil and geological samples can be recorded in situ and to a high degree of 437 spatial accuracy, thereby resolving the issue of contextual and provenance problems. The work 438 presented here is the first of its kind conducted on the site since 1947-1948, reinforcing the need 439 for these types of surveys to be conducted, both in the context of ongoing excavation and with 440 the analysis of historical collections.

441

442 Given our comparison of Peabody's original map with published material and the errors in 443 naming identified (Fig. 3), we strongly recommend that all pits be referenced by their number or 444 original title where possible (Table 1; Fig. 2). For the majority of pits across the site this is the 445 numerical designator assigned during the UCAE (e.g. Pits 1-23). However, for all truly new sites subsequently discovered (e,g. Waypoint 160), their first published name should be used to prevent any further confusion. Since no material was recovered from "Bushman outcrop" it should henceforth be known by the first name associated with published faunal material "Milo". Additionally, due to the questionable name attributed Pit 3 by the UCAE, the numerical designator (3) or new HRU name (Cobra Cave) is favoured (Table 1).

Biochronological assessment of the faunal specimens from the Pits suggests that parts of the Bolt's Farm complex may be the oldest in the Blaubank Stream Valley, possibly forming as early as the mid- (e.g. Pits 7 and 10) or late (e.g. Pits 14, 23 and Milo's A) Pliocene, and therefore 455 prior or contemporaneous with the formation of the Makapansgat Member 3 deposits (3.03-2.58 $\mathrm{Ma}$; Herries et al. 2013). Recent U-Pb ages for flowstones at some of these deposits (Pit 7, Pit 
458 combined with in depth stratigraphic interpretation and other chronological methods. These ages 459 appear to suggest that deposits within the Cradle are all younger than $\sim 3.2 \mathrm{Ma}$. With a combined 460 record that may span over 2 Ma of deposition, Bolt's Farm represents - alongside Sterkfontein 461 one of few site complexes to cover such a long span of time in the Cradle region, providing a 462 rare opportunity for more detailed comparisons of the fauna from these different localities 463 through time (Pickering et al.,2018; Herries et al., 2018).

464 Additionally, within the Cradle it is unusual to have an extensive site complex like Bolt's Farm 465 that is devoid of hominin specimens, and a small non-hominin primate sample, in such close 466 proximity to well-known hominin- and primate-bearing sites (e.g. Sterkfontein, Swartkrans, 467 Rising Star). There are many potential reasons why hominins or primates may not occur within 468 the Bolt's Farm deposits which warrant mention. There are numerous references within the 469 original field notes of Camp to australopithecine and "ape man" remains from Pit 3 (SOM SF6.

470 SF7. SF8); however, these specimens are not known to have been subsequently catalogued 471 within any current collections. It is possible that these specimens were incorrectly identified in 472 the field (e.g. reclassified as non-hominin primate or other mammal remains), or that they were 473 accidentally integrated into other fossil samples during the removal of Bolt's Farm materials 474 which saw them organised and packed at the Ditsong National Museum of Natural History prior 475 to export. We can establish that some specimens were simply never accessioned. For example, 476 while Pit 3 is the only location from which a single stone tool is known to have been recovered;

477 however, Camp's notes provide insight citing that he "scraped out 10-15 blades and gave them to 478 the (Bolt) sisters" (SOM SF9). He goes on to list artefacts "thin blades, quartz chips. One core of 479 chert and some slate artefacts"; none of these artefacts are known today. Equally, variable 480 taphonomic processes exert a strong mediating role in faunal assemblage composition (Brain, 481 1981; Pickering, 1999; Adams, 2006; Pickering et al., 2004; Val \& Stratford., 2015) and the 482 taphonomic histories of these Pits have not yet been addressed (excepting Pit 23; see Brain, 483 1981). Ultimately, it is important to highlight that a bias towards excavating and analysing the 484 well-known hominin fossil sites located nearby may be distorting our perception of how 485 regularly hominins, primates and archaeological materials were integrated into the Cradle 486 localities. In this respect, the Bolt's Farm Pits may be typical of penecontemporaneous 487 deposition across the region in representation of fauna. 
490 In the more than 80 years since Broom first prospected at Bolt's Farm, continued research has 491 proven the value of the site to yield important palaeontological remains, the summed sample of 492 which indicates an extensive depositional history that has been suggested to date back into the 493 Pliocene.

Bolt's Farm differs significantly from other sites in the Cradle in two ways. Firstly, while palaeokarst features are commonplace throughout the Cradle, most fossil bearing sites are either caves (e.g. Sterkfontein) or single palaeokarst deposits (eg. Malapa). It is unprecedented to have such a high density of fossil bearing palaeokarst deposits and active caves in a small area, as is the case at Bolt's Farm. Additionally, biochronology suggests there is significant temporal variation within, and between, the more than twenty known localities across the site. The unique conditions which have led to the preservation of so many palaeokarst remnants and caves is inherently linked to the geology observed at the site, requiring further research to fully disentangle.

It is critical to the next stage of research at Bolt's Farm that all areas be accurately mapped and a uniform naming scheme be settled on. As a result, the detailed survey provided here seeks to clarify the naming issues and we present the first new map of the site in more than 70 years. Our study highlights the importance of field survey paired with high-resolution spatial mapping and drone survey, as our new map and site surveying control points allow the historical fossil collection to be accurately placed within its original context. The continued use of $3 \mathrm{D}$ data collection methodologies at the site will rectify some of the problems researchers have encountered. Although the site has been disturbed by mining activities and some contexts

513 destroyed, the importance of this information is only being realised as new methods enable these

514 distinct areas to be dated. While additional biochronological dating (after full description of more

515 recently excavated faunas) and absolute dating methods will provide clarification of the age of 516 deposits, spatial aids provided here should be adopted by researchers continuing to excavate at

517 Bolt's Farm, to ensure an accurate spatial and contextual record of all finds from this key

518 palaeontological site in the Cradle. 


\section{ACKNOWLEDGEMENTS}

522 The authors wish to thank Dr. Robert Anemone and one anonymous reviewer for helpful 523 suggestions which improved this manuscript. The authors wish to thank Stepheny Potze and

524 Lazarus Kgasi for access to the site and assistance with fieldwork, Stephany Potze was the 525 SAHRA permit holder at time of sample collection; Dominique Gommery and Lazarus Kgasi 526 SAHRA permit holders during surface survey; Ditsong National Museum of Natural History; Pat 527 Holroyd for access to original notes and collections of UCAE, UCMP ; Tara R. Edwards thanks 528 Tesla Monson for assistance, support and helpful discussion, Justin W. Adams thanks Alan 529 Shabel for assistance, support and expertise at UCMP; J Gaylord, landowner of Greensleeves. 530 We thank Norbert Plate of iQlaser (www.iqlaser.co.za) for his time, equipment and provision of 531 aerial imagery. Elevation data available from USGS.

532

\section{CONTRIBUTIONS}

534 TRE, PP-K and JBR conducted DGPS survey of Bolt's Farm. BJA facilitated aerial drone survey 535 and the establishment of datum points. Data processing was carried out by BJA, PP-K, AFB and 536 TRE. Map production was carried out by TRE. JWA conducted faunal analysis. The project was 537 conceived of and funded by AIRH and JWA. All authors contributed to the production of the 538 manuscript.

539

540 FUNDING STATEMENT:

541 Funding received from the Australian Research Council (grant FT120100399 and DP170100056

542 to AIRH) and the La Trobe University Humanities and Social Science Internal Research Grant 543 (\#2017-1-HDR-0009 to TRE and \#2015-1-HDR-1 to BJA) and National Research Foundation 544 African Origins Platform (grant AOP150924142990 to RP).

545

\section{References}

547 Adams, J., 2006. Taphonomy and palaeoecology of the Gondolin Plio-Pleistocene cave site, 548 South Africa. Unpublished Ph.D. Thesis, Washington University, St. Louis. 
550 Adams, J. W., Olah, A. H., McCurry, M. R. \& Potze, S. 2015. Surface model and tomographic

551 archive of fossil primate and other mammal holotype and paratype specimens of the Ditsong

552 National Museum of Natural History, Pretoria, South Africa, PLoS ONE. 10, 10, 14 p.,

553 e0139800 DOI: 10.1371/journal.pone.0139800

554

555

Anemone, R.L., Conroy, G.C., Emerson, C. W. 2011. GIS and Paleoanthropology :

556

Incorporating New Approaches from the Spatial Sciences in the Analysis of Primate and Human

557

Evolution. Yearbook of Physical Anthropology. 54, 19-46.

558

559

Armstrong, B. J., Blackwood, A. F., Penzo-Kajewski, P., Mentor, C. G., Herries, A. I. R. 2018.

560

Terrestrial laser scanning and photogrammetry techniques for documenting fossil-bearing

561

palaeokarst with an example from the Drimolen Palaeocave System, South Africa.

562 Archaeological Prospection. 25, 1, 45-58. DOI: 10.1002/arp.1580

563

564

Bailey, G.N., Reynolds, S.C., King, G.C.P. 2011. Landscapes of human evolution: models and

565

methods of tectonic geomorphology and the reconstruction of hominin landscapes. Journal of

566

Human Evolution. 60, 257-280

567

568

Berger, L. R. Hawks, J. De Reuiter, D. J. Churchill, S. E. Schmid, P. Delezene, L. K. Kivell, T.

569

L. Garvin, H. M. Williams, S. A. Desilva, J. M. Skinner, M.M. Musiba, C. M. Cameron, N.

570 Holliday, T. W. Harcourt-Smith, M. Ackermann, R. R. Bastir, M. Bogin, B. Bolter, D. Brophy, Cofran, Z. D. Congdon, K. A. Deane, A. S. Dembo, M. Drapeau, M. Elliot, M. C. Feurriegel, E. M. Garcia-Martinez, D. Green, D. J. Gurtov, A. Irish, J. D. Kruger, A. Lairs, M. F. Marchi, D. Meyer, M. R. Nalla, S. Negash, E. W. Orr, C. M. Radovcic, D. Schroeder, L. Scott, J. E. naledi a new species of the genus Homo from the Dinaledi Chamber, South Africa. eLife, 4, e09560. DOI: 10.7554/eLife.09560 and Spatial Relations of Fossil Deposits at Wonderwerk Cave (South Africa). African Archaeological Review. 32, 4, 857-876. 
582 Brain C. 1981. The hunters or the hunted? An introduction to African cave taphonomy. Chicago: 583 University of Chicago Press. ISSN: 0226070905

584

585 Braun, D. R., Levin, N. E., Stynder, D., Herries, A. I. R., Archer, W., Forrest, F., Roberts, D. L., 586 Bishop, L. C., Matthews, T., Lehmann, S. B., Pickering, R., Fitzsimmons, K. E. 2013. Mid

587 Pleistocene hominin occupation at Elandsfontein, Western Cape, South Africa. Quaternary

588 Science Reviews. 82, 145-166. DOI: 10.1016/j.quasci.2013.09.027

589

590 Broom, R. 1937. Notices of a few more new fossil mammals from the caves of the Transvaal.

591 Annals and Magazine of Natural History 20, 509-514. DOI: 10.1080/00222933708655373

592

593 Broom, R. 1939. A preliminary account of the Pleistocene carnivores of the Transvaal caves.

594 Annals of the Transvaal Museum 19, 331-338. ISSN:0041-1752

595

596 Camp, C.L. 1948. University of California African expedition - southern section. Science 108, 597 550-552. DOI: 10.1126/science.108.2812.550

599 Conroy,G., Anemone, R., Van Regenmorter, J., Addison, A. 2008. Google Earth, GIS, and the

600 Great Divide: a new and simple method for sharing palaeontological data. Journal of Human 601 Evolution. 55, 751-755.

602

603 Cooke, H.B.S. 1963. Pleistocene mammal faunas of Africa, with particular reference to southern 604 Africa. In: HOWELL, F.C. BOURLIÈRE, F. (eds.), African ecology and human evolution.

605 Aldine press, Chicago, 65-116.

606

607 Cooke, H.B.S. 1985. Ictonyx bolti, a new mustelid from cave breccias at bolt's farm,

608 Sterkfontein area, South African Journal of Science 81, 618-619. ISSN: 0038-2353

609 
610 Cooke, H.B.S. 1991. Dinofelis barlowi (Mammalia, Carnivora, Felidae) cranial material from

611 Bolt's Farm, collected by the University of California African expedition. Palaeontologica

612 africana. 28, 9-21. URI: 10539/16164

613

614 Cooke, H.B.S. 1993. Undescribed suid remains from Bolt's Farm and other Transvaal cave

615 deposits. Palaeontologica africana 30, 7-23. URI: 10539/16235

616

617 Dart, R. A. 1925. Australopithecus africanus: The Man-Ape of South Africa. Nature. 115, 195-

618 199. DOI: $10.1038 / 115195 \mathrm{a} 0$

619

620 Delson, E. 1984. Cercopithecid biochronology of the African Plio-Pleistocene: correlation

621 among eastern and southern hominid-bearing localities. Courier Forschungsinstitut Senckenberg $62269,199-218$.

623

6aA1 Del la Torre, I., Arroyo, A., Proffitt, T., Martín Ramos, C., Theodoropoulou, A. 2015.

625 Archaeological fieldwork techniques in Stone Age sites. Treballs d'arqueologia. 20, 0021-0040.

626

627 Dell'Unto, N., Landeschi, G., Apel, J., Poggi, G. 2017. 4D recording at the trowel's edge: Using 628 three-dimensional simulation platforms to support field interpretation. Journal of Archaeological 629 Science: Reports.12, 632-645.

630

631 Dirks, P.H.G.M. Berger, L. R. Roberts, E. M. Kramers, J. D. Hawks, J. Randolph-Quinney, P. S. 632 Elliott, M. Musiba, C. M. Churchoff, S. E. De Ruiter, D. J. Schmid, P. Backwell, L. R. Belyanin, 633 G. A. Boshoff, P. Hunter, K. L. Feurriegel, E. M. Gurtov, A. Harrison, J, D. G. Hunter, R.

634 Kruger, A. Morris, H. Makhubela, T. V. Peixotto, B.\& Tucker, S. 2015. Geological and

635 taphonomic context for the new hominin species Homo naledi from the Dinaledi chamber, South 636 Africa. eLife, 4, .e09561. DOI: 10.7554/eLife.09561

637

638 Fernández-Lozano, J., Gutiérrez-Alonso, G. 2016. Improving archaeological prospection using 639 localized UAVs assisted photogrammetry: An example from the Roman Gold District of the Eria 
640 River Valley (NW Spain). Journal of Archaeological Science: Reports. 5,509-520.

641

642 Geraads D, Raynal J, and Eisenmann V. 2004. The earliest human occupation of North Africa:a

643 reply to Sahnouni et al. (2002). Journal of Human Evolution 46:751-761.DOI:

644 10.1016/j.jhevol.2004.01.008

645

646 Gibbons, A. 1991. A “new look” for archaeology. Science, 252, 918-920.

647

648 Gommery, D. Thackeray, J.F. sénégas, F. Potze, S. Kgasi, L. 2008A. The earliest primate

649 (Parapapio sp.) From the Cradle of Humankind World Heritage Site (Waypoint 160, Bolt's Farm, 650 South Africa). South African Journal of Science 104,405-408.

651

652 Gommery, D. Sénégas, F. \& Thackeray, J.F. 2008B. Plio-Pleistocene fossils from femur dump, 653 Bolt's Farm, Cradle of Humankind World Heritage Site. Annals of the Transvaal Museum 45, 654 67-76. ISSN : 0041-1752

655

656 Gommery, D., Badenhorst, S., Potze, S., Senegas, F., Kgasi, L., and Thackeray, J.F. 2012. 657 2012. Preliminary results concerning the discovery of new fossiliferous sites at Bolt's Farm 658 (Cradle of Humankind, South Africa). Annals of the Ditsong national Museum of Natural 659 History 2, 33-45. ISSN : 2220-4563

660

661 Gommery, D. Sénégas, F. Potze, S. Kgasi, L. \& Thackeray, J. F. 2014. Cercopithecoidea 662 material from the Middle Pliocene Site, Waypoint 160, Bolt's Farm, South Africa. Annals of the 663 Ditsong Museum of Natural History 4, 1-8. ISSN : 2220-4563

664

665 Gommery, D. Sénégas, F. Kgazsi, L. Vilakazi, N. Kuhn, B. Pickford, M. Herries, A. I. R.

666 Hancox, J. Saos, T. Segalen, L. Aufort, J. \& Thackeray, J. F. 2016. Bolt's Farm cave system 667 dans le cradle of humankind (Afrique du Sud) : un exemple d'approche multidisciplinaire dans 668 l'étude des sites à primates fossiles. Revue de primatologie. 7. 
670 Herries, A. I. R. 2003. Magnetostratigraphic seriation of South African hominin palaeocaves.

671 Unpublished Ph.D thesis, University of Liverpool, Liverpool.

672

673 Herries, A. I. R., Pickering, R., Adams, J. W., Curnow, D., Warr, G., Latham, A. G., Shaw, J.

674 2013. A multi-disciplinary perspective on the age of Australopithecus in Southern Africa. In:

675 Reed K., Fleagle J., Leakey R. (eds) The Paleobiology of Australopithecus. Vertebrate

676 Paleobiology and Paleoanthropology. Springer, Dordrecht. DOI: 10.1007/978-94-007-5919-0_3

677

678 Herries, A. I. R,m Murszewski, A., Pickering, R., Mallett, T., Johannes-Boyau, R., Armstrong, 679 B., Adams, J. W., Baker, S., Blackwood, A. F., Penzo-Kajewski, P., Kappen, P., Leece, A. B., 680 Martin, J., Rovinsky, D., Boschiani, G. 2018. Geoarchaeological and 3D visualisation 681 approaches for contextualising in-situ fossil bearing palaeokarst in South Africa: A case study 682 from the $\sim 2.61$ Ma Drimolen Makondo. Quaternary International, 483, 90-110.

683 DOI:10.1016/j.quaint.2018.01.001

684

685

686

Holmes, K. 2007. GIS simulation of the earliest hominid colonisation of Eurasia. Oxford:

Archaeopress.154.

687

688

689

Jarvis, a., Reuter, H.I., Nelson, A., Guevera,E. 2008. Hole-filled SRTM for the globe Version 4, available from the CGIAR-CSI STRM 90m Database.

690

691

692 Jorayev, G., Wehr, K., Benito-Calvo, A., Njau, J., de la Torre, I. 2016. Imaging and

693 photogrammetry models of Olduvai Gorge (Tanzania) by Unmanned Aerial Vehicles: A high-

694 resolution digital database for research and conservation of Early Stone Age sites. Journal of

695 Archaeological Science. 75, 40-56.

696

697 Klein, R. G., Avery. G., Cruz-Uribe, K., Steele, T. E. 2007. The mammalian fauna associated 698 with an archaic hominin skullcap and later Acheulean artifacts at Elandsfontein, Western Cape 699 Province, South Africa. Journal of Human Evolution. 52, 164-186. DOI:

$700 \quad 10.1016 /$ j.jhevol.2006.08.006 
701 Linnaeus, C. 1758. Systema naturae per regna tria naturae, secundum classes, ordines, genera,

702 species, cum characteribus, differentiis, synonymis, locis. Editio decima, reformata.

703 Holmiae,Stockholm. Laurentii Salvii.

704

705 Lock, G. \& Stancic, Z. (eds) 1995. GIS in archaeology: a European perspective. London: Taylor 706 \& Francis.

707

708

Mokokwe, W. D. 2007. Goldsmiths: Preliminary study of a newly discovered Pleistocene site 709 near Sterkfontein. Unpublished MSc Thesis, University of the Witwatersrand, Johannesburg.

710

711

Monson, T.A. Brasil, M.F. \& Hlusko, L. J. 2015. Materials collected by the southern branch of

712 the UC Africa Expedition with a report on previously unpublished Plio-Pleistocene fossil

713 localities. Paleobios 32, 1-17.

714

715 Nigro, J. D., Ungar, P.S., de Ruiter, D. J., Berger, L. R. 2003. Developing a Geographic

716 Information System (GIS) for Mapping and Analysing Fossil Deposits at Swartkrans, Gauteng

717 Province, South Africa. Journal of Archaeological Science, 30, 317-324. DOI:

$718 \quad 10.1006 /$ jasc. 2002.0839

719

720

Oheim, K. B. 2007. Fossil site prediction using geographic information systems (GIS) and

721 suitability analysis: The Two Medicine formation, a test case. Palaeogeography,

722

Palaeoclimatology, Palaeoecology. 251, 3-4, 354-365. DOI: 10.1016/j.palaeo.2007.04.005

723

724 Partridge, T. C. 1973. Geomorphological dating of cave openings at Makapansgat, Sterkfontein, 725 Swartkrans and Taung. Nature 246, 75-79.

726

727 Peabody, F.E. 1954. Travertines and cave deposits of the Kaap escarpment of South Africa, and 728 the type locality of Australopithecus africanus Dart. Geological Society of America Bulletin $72965,671-706$. 
731 Pickering, T. R. 1999. Taphonomic Interpretations of the Sterkfontein Early Hominid Site

732 (Gauteng, South Africa) Reconsidered in Light of Recent Evidence. Unpublished PhD Thesis.

733 University of Wisconsin, Madison.

734

735 Pickering, T. R., Dominguez-Rodreigo, M., Egeland, C. P., Brain, C. K. 2004. Beyond leopards:

736 tooth marks and the contribution of multiple carnivore taxa to the accumulation of the

737 Swartkrans Member 3 fossil assemblage. Journal of Human Evolution 46, 5, 595-604.

738 DOI: $10.1016 /$ j.jhevol.2004.03.002

739

740 Pickering, R., Herries, A. I. R., Woodhead, J.D., Hellstrom, J. C., Green, H. E., Paul, B.,

741 Ritzman, T., Strait, D., Schoville, B. J., Hancox, H. 2018. U-Pb dated flowstones restrict South

742 African early hominin record to dry climate phases. Nature. DOI:10.1038/s41586-018-0711-0

743

744 Pickford, M.\& Gommery, D. 2016. Fossil suidae (Artiodactyla, Mammalia) from Aves Cave and 745 nearby sites in Bolt's Farm palaeokarst system, South Africa. Estudios geológicos 72, e059.

746 DOI: $10.3989 /$ egeol.42389.404

747

748 Reynolds, S.C. 2007. Temporal variation in Plop-Pleistocene Antidorcas (Mammalia, Bovidae)

749 horncores: The Case from Bolt's Farm and why size matters. South African Journal of Science 750 103, 47-50. ISSN: 1996-7489

751

752 Sénégas, F. \& Avery, D.M. 1998. New evidence for the murine origins of the otomyinae

753 (Mammalia, Rodentia) and the age of Bolt's Farm (South Africa). South African Journal of 754 Science 94, 503-507.

755

756 Sénégas, F. 2000. Les faunes de rongeurs (Mammalia) Plio-Pléistocènes de la province de

757 Gauteng(Afrique du Sud): mises au point et apports systématiques, biochronologiques et

758 précisions paléoenvironnementales. Non publiée thèse doctorat, Universitémontpellier ii et ephe, 759 Montpellier, France. 
761 Sénégas, F. Thackeray, J. F. Gommery, D. \& Braga, J. 2002. Scientific notes palaeontological

762 sites on 'Bolt's Farm', Sterkfontein valley, South Africa. Annals of the Transvaal Museum 39,

763 65-67. DOI: 10.4000/primatologie.2715

764

765 Thackeray, J.F. Gommery, D. Sénégas, F. Potze, S. Kgasi, L. Mcgrae, C.\& Prat, S. 2008. A

766 survey of past and present work on Plio-Pleistocene deposits on Bolt's Farm, Cradle of

767 Humankind, South Africa. Annals of the Transvaal Museum 45,83-89. ISSN: 0041-1752

768

769 Trueman CNG, Field JH, Dortch J, Charles B, Wroe S. 2005. Prolonged coexistence of humans

770 and megafauna in Pleistocene Australia. Proceedings of the National Academy of Sciences 102:

771 8381-8385. DOI:10.1073/pnas.0408975102

772

773 Val, A. \& Stratford, D. J. 2015. The macrovertebrate fossil assemblage from the Name Chamber,

774 Sterkfontein: Taxonomy, taphonomy and implications for site formation processes.

775 Palaeontologica Africana 50, 1-17. URI: http://hdl.handle.net/10539/18819

776

777 Werdelin L, and Peigne S. 2010. Carnivora. In: Werdelin L, and Sanders W, eds. Cenozoic

778 mammals of Africa. Berkeley: University of California Press, 603-658. 


\section{Table $\mathbf{1}$ (on next page)}

Known locations across Bolt's Farm and various names within the literature, sorted by source. Coordinates from DGPS survey given in South African Grid and UTM. 


\begin{tabular}{|c|c|c|c|c|c|c|c|c|c|c|c|}
\hline $\begin{array}{l}\text { Peabody, } \\
\text { unpublished } \\
\text { (1947) }\end{array}$ & $\begin{array}{l}\text { UCMP } \\
\text { Locality }\end{array}$ & $\begin{array}{l}\text { Cooke } \\
\text { (1991) }\end{array}$ & $\begin{array}{l}\text { Sénégas et al. } \\
\text { (2002) }\end{array}$ & $\begin{array}{l}\text { Thackeray } \\
\text { et al. (2008) }\end{array}$ & $\begin{array}{l}\text { Zipfel \& } \\
\text { Berger } \\
\text { (2009) }\end{array}$ & $\begin{array}{l}\text { Gommery et } \\
\text { al. (2012) }\end{array}$ & $\begin{array}{l}\text { Monson et } \\
\text { al. (2015) }\end{array}$ & $\begin{array}{l}\text { Pickford \& } \\
\text { Gommery } \\
\text { (2016) }\end{array}$ & $\begin{array}{l}\text { Edwards et } \\
\text { al. (2018) }\end{array}$ & $\begin{array}{l}\text { SA } \\
\text { Hartebeesthoek } \\
\text { 94/ Lo27 }\end{array}$ & UTM -35 \\
\hline $\begin{array}{l}\text { Pit } 1 \\
\text { (Kraal Pit) }\end{array}$ & $\begin{array}{l}\text { V67256, } \\
\text { V75133 }\end{array}$ & $\begin{array}{l}\text { Pit } 1 \\
\text { Kraal Pit }\end{array}$ & Pit 1 & Kraal Pit & $\begin{array}{l}\text { Kraal Pit } \\
\text { (Pit 1) }\end{array}$ & Pit 1 & \begin{tabular}{|l|} 
Pit 1 \\
(Kraal Pit)
\end{tabular} & Pit 1 & Pit 1 & $\begin{array}{l}-71816.550 \mathrm{Y} \\
2880218.092 \mathrm{X} \\
\end{array}$ & $\begin{array}{l}7120933.995 \mathrm{~N} \\
571787.823 \mathrm{E} \\
\end{array}$ \\
\hline $\begin{array}{l}\text { Pit } 2 \\
\text { (Kiln Cave) }\end{array}$ & V67257 & $\begin{array}{l}\text { Pit } 2 \\
\text { Kiln }\end{array}$ & Pit 2 & H Cave & $\begin{array}{l}\text { H Cave } \\
\text { (Pit 2) }\end{array}$ & $\mathrm{N} / \mathrm{A}$ & $\begin{array}{l}\text { Pit } 2 \\
\text { (Kiln Pit) }\end{array}$ & H Cave & Pit 2 & $\begin{array}{l}-71808.454 \mathrm{Y} \\
2880137.641 \mathrm{X}\end{array}$ & $\begin{array}{l}7121014.414 \mathrm{~N} \\
571779.731 \mathrm{E}\end{array}$ \\
\hline $\begin{array}{l}\text { Pit } 3 \\
\text { (KB Cave) }\end{array}$ & $\begin{array}{l}\text { V67258, } \\
\text { V75132 }\end{array}$ & $\begin{array}{l}\text { Pit } 3 \\
\text { KB Cave }\end{array}$ & Pit 3 & Cobra Cave & $\begin{array}{l}\text { KB/Cobra } \\
\text { Cave (Pit } \\
3 \text { ) } \\
\end{array}$ & Cobra Cave & $\begin{array}{l}\text { Pit } 3 \\
\text { (Cobra } \\
\text { Cave) } \\
\end{array}$ & Cobra Cave & \begin{tabular}{|l|} 
Pit 3 \\
(Cobra \\
Cave) \\
\end{tabular} & $\begin{array}{l}-71775.725 \mathrm{Y} \\
2880150.923 \mathrm{X}\end{array}$ & $\begin{array}{l}7121001.137 \mathrm{~N} \\
571747.015 \mathrm{E}\end{array}$ \\
\hline $\begin{array}{l}\text { Pit } 4 \\
\text { (Garage } \\
\text { Ravine) }\end{array}$ & V67259 & $\begin{array}{l}\text { Pit } 4 \\
\text { Garage } \\
\text { Ravine } \\
\text { Cave } \\
\end{array}$ & Pit 4 & $\begin{array}{l}\text { Garage } \\
\text { Ravine } \\
\text { Cave }\end{array}$ & $\begin{array}{l}\text { Garage } \\
\text { Ravine } \\
\text { Cave (Pit } \\
4 \text { ) }\end{array}$ & $\begin{array}{l}\text { Garage } \\
\text { Ravine Cave }\end{array}$ & $\begin{array}{l}\text { Pit } 4 \\
\text { (Garage } \\
\text { Ravine } \\
\text { Cave) } \\
\end{array}$ & $\begin{array}{l}\text { Garage } \\
\text { Ravine }\end{array}$ & Pit 4 & $\begin{array}{l}-71623.214 \mathrm{Y} \\
2880568.009 \mathrm{X}\end{array}$ & $\begin{array}{l}7120584.218 \mathrm{~N} \\
571594.565 \mathrm{E}\end{array}$ \\
\hline $\begin{array}{l}\text { Pit } 5 \text { (Smith } \\
\text { Cave) }\end{array}$ & $\begin{array}{l}\text { V67260, } \\
\text { V75139 }\end{array}$ & $\begin{array}{l}\text { Pit } 5 \\
\text { Smith } \\
\text { Cave } \\
\end{array}$ & Pit 5 & $\begin{array}{l}\text { Smith Cave- } \\
\text { misidentifie } \\
\text { d }\end{array}$ & $\begin{array}{l}\text { Smith } \\
\text { Cave } \\
\text { (Pit 5) } \\
\end{array}$ & Smith Cave & $\begin{array}{l}\text { Pit } 5 \\
\text { (Smithy } \\
\text { Cave) }\end{array}$ & $\begin{array}{l}\text { Aves Cave } 4 \\
\text { (listed as Pit } \\
13 \text { ) }\end{array}$ & Pit 5 & $\begin{array}{l}-71692.381 \mathrm{Y} \\
2880228.869 \mathrm{X}\end{array}$ & $\begin{array}{l}7120923.223 \mathrm{~N} \\
571663.704 \mathrm{E}\end{array}$ \\
\hline $\begin{array}{l}\text { Pit } 6 \text { (Baboon } \\
\text { Cave) }\end{array}$ & V67261 & $\begin{array}{l}\text { Pit } 6 \\
\text { Baboon } \\
\text { Cave } \\
\end{array}$ & Pit 6 & $\begin{array}{l}\text { Baboon } \\
\text { Cave }\end{array}$ & $\begin{array}{l}\text { Baboon } \\
\text { Cave (Pit } \\
6 \text { ) } \\
\end{array}$ & Baboon Cave & $\begin{array}{l}\text { Pit 6 } \\
\text { (Baboon } \\
\text { Cave) } \\
\end{array}$ & Baboon Cave & Pit 6 & $\begin{array}{l}-71196.127 \mathrm{Y} \\
2880661.711 \mathrm{X}\end{array}$ & $\begin{array}{l}7120490.554 \mathrm{~N} \\
571167.649 \mathrm{E}\end{array}$ \\
\hline $\begin{array}{l}\text { Pit } 7 \\
\text { (Elephant } \\
\text { Cave) }\end{array}$ & V67262 & $\begin{array}{l}\text { Pit } 7 \\
\text { Elephant } \\
\text { Cave }\end{array}$ & Pit 7 & Bridge Cave & $\begin{array}{l}\text { Elephant/ } \\
\text { Bridge } \\
\text { Cave (Pit } \\
7 \text { ) }\end{array}$ & Bridge Cave & $\begin{array}{l}\text { Pit } 7 \\
\text { (Elephant } \\
\text { Cave) }\end{array}$ & Bridge Cave & Pit 7 & $\begin{array}{l}-71348.713 \mathrm{Y} \\
2880563.021 \mathrm{X}\end{array}$ & $\begin{array}{l}7120589.204 \mathrm{~N} \\
571320.174 \mathrm{E}\end{array}$ \\
\hline Pit 8 & V75269 & Pit 8 & N/A & $\begin{array}{l}\text { Rodent } \\
\text { Cave }\end{array}$ & $\begin{array}{l}\text { Rodent } \\
\text { Cave (Pit } \\
8 \text { ) }\end{array}$ & Rodent Cave & $\begin{array}{l}\text { Pit } 8 \\
\text { (Rodent } \\
\text { Cave) }\end{array}$ & Aves Cave 2 & Pit 8 & $\begin{array}{l}-71700.181 \mathrm{Y} \\
2880266.450 \mathrm{X}\end{array}$ & $\begin{array}{l}7120885.656 \mathrm{~N} \\
571671.501 \mathrm{E}\end{array}$ \\
\hline Pit 9 & N/A & Pit 9 & Pit 9 & No name & $\begin{array}{l}\text { No name } \\
\text { (Pit 9) }\end{array}$ & N/A & N/A & Pit 9 & N/A & $\begin{array}{l}-71790.951 Y \\
2880193.79 X\end{array}$ & $\begin{array}{l}7120958.288 \mathrm{~N} \\
571762.235 \mathrm{E}\end{array}$ \\
\hline $\begin{array}{l}\text { Bushman } \\
\text { Outcrop }\end{array}$ & N/A & $\begin{array}{l}\text { Breccia } \\
\text { outcrop }\end{array}$ & $\begin{array}{l}\text { Breccia } \\
\text { Outcrop }\end{array}$ & $\begin{array}{l}\text { Breccia } \\
\text { Outcrop }\end{array}$ & N/A & Milo A & N/A & Milo A & Milo & $\begin{array}{l}-71131.98 \mathrm{Y} \\
2880625.805 \mathrm{X} \\
\end{array}$ & $\begin{array}{l}7120526.445 \mathrm{~N} \\
571103.527 \mathrm{E} \\
\end{array}$ \\
\hline Pit 10 & V67263 & $\begin{array}{l}\text { Pit } 10 \\
\text { Grey Bird } \\
\text { Pit }\end{array}$ & N/A & $\begin{array}{l}\text { Main } \\
\text { Quarry }\end{array}$ & $\begin{array}{l}\text { Grey Bird } \\
\text { Pit/Main } \\
\text { Quarry } \\
\text { (Pit 10) }\end{array}$ & $\mathrm{N} / \mathrm{A}$ & N/A & N/A & N/A & 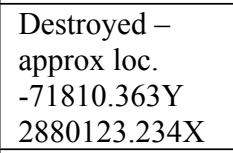 & $\begin{array}{l}7121028.815 \mathrm{~N} \\
571781.639 \mathrm{E}\end{array}$ \\
\hline Pit 11 & N/A & Pit 11 & Pit 11 & U Cave & $\begin{array}{l}\text { N/A (Pit } \\
11) \\
\end{array}$ & X Cave & N/A & X Cave & Pit 11 & $\begin{array}{l}71569.186 \mathrm{Y} \\
2880320.273 \mathrm{X}\end{array}$ & $\begin{array}{l}7120831.855 \mathrm{~N} \\
571540.558 \mathrm{E}\end{array}$ \\
\hline Pit 12 & N/A & Pit 12 & Pit 12A & No name & $\begin{array}{l}\text { No name } \\
\text { (Pit 12A) }\end{array}$ & Pit 12 (A) & N/A & Pit $12(\mathrm{~A})$ & Pit 12 & $\begin{array}{l}-71487.209 \mathrm{Y} \\
2880393.871 \mathrm{X}\end{array}$ & $\begin{array}{l}7120758.287 \mathrm{~N} \\
571458.614 \mathrm{E}\end{array}$ \\
\hline N/A & N/A & N/A & Pit 12B & N/A & $\begin{array}{l}\text { No Name } \\
\text { (Pit 12B) }\end{array}$ & Pit 12B & N/A & Pit $12 \mathrm{~b}$ & Pit 12B & $\begin{array}{l}-71377.978 \mathrm{Y} \\
2880444.538 \mathrm{X}\end{array}$ & $\begin{array}{l}7120707.640 \mathrm{~N} \\
571349.426 \mathrm{E}\end{array}$ \\
\hline
\end{tabular}




\begin{tabular}{|c|c|c|c|c|c|c|c|c|c|c|c|}
\hline Pit 13 & N/A & Pit 13 & $\begin{array}{l}\text { Pit } 13- \\
\text { Misidentified } \\
\text { (Pit } 5 \text { was } \\
\text { mapped) }\end{array}$ & Arm Pit & (Pit 13) & N/A & N/A & Aves Cave 5 & N/A & $\begin{array}{l}-71684.94606 \mathrm{Y} \\
2880222.8518 \mathrm{X}\end{array}$ & $\begin{array}{l}7120929.237 \mathrm{~N} \\
571656.272 \mathrm{E}\end{array}$ \\
\hline $\begin{array}{l}\text { Pit } 14 \text { (Bench } \\
\text { mark Pit) }\end{array}$ & V67264 & $\begin{array}{l}\text { Pit 14 } \\
\text { Benchmar } \\
\text { k Pit }\end{array}$ & Pit 14 & $\begin{array}{l}\text { Benchmark } \\
\text { Pit }\end{array}$ & $\begin{array}{l}\text { Bench } \\
\text { Mark Pit } \\
\text { (Pit 14) }\end{array}$ & $\begin{array}{l}\text { Benchmark } \\
\text { Pit }\end{array}$ & $\begin{array}{l}\text { Pit } 14, \\
\text { Benchmark } \\
\text { Pit, } \\
\text { Location } 10\end{array}$ & Aves Cave 1 & Pit 14 & $\begin{array}{l}-71680.196 \mathrm{Y} \\
2880248.291 \mathrm{X}\end{array}$ & $\begin{array}{l}7120903.808 \mathrm{~N} \\
571651.524 \mathrm{E}\end{array}$ \\
\hline Pit 15 & V73105 & Pit 15 & $\begin{array}{l}\text { Pit 15- } \\
\text { Misidentified }\end{array}$ & Aves Cave & $\begin{array}{l}\text { Aves } \\
\text { Cave (Pit } \\
15)\end{array}$ & Aves & $\begin{array}{l}\text { Pit } 15, \\
\text { Aves, } \\
\text { Location } 11\end{array}$ & Aves Cave 6 & Pit 15 & $\begin{array}{l}-71671.637 \mathrm{Y} \\
2880262.266 \mathrm{X}\end{array}$ & $\begin{array}{l}7120889.838 \mathrm{~N} \\
571642.968 \mathrm{E}\end{array}$ \\
\hline $\begin{array}{l}\text { Pit } 16 \text { (Equine } \\
\text { Pit) }\end{array}$ & V67265 & $\begin{array}{l}\text { Pit } 16 \\
\text { Equine } \\
\text { Pit- cut } \\
\text { off map }\end{array}$ & N/A & N/A & $\mathrm{N} / \mathrm{A}$ & Milo B & $\mathrm{N} / \mathrm{A}$ & Milo B & Pit 16 & $\begin{array}{l}-71109.010 \mathrm{Y} \\
2880649.901 \mathrm{X}\end{array}$ & $\begin{array}{l}7120502.359 \mathrm{~N} \\
571080.566 \mathrm{E}\end{array}$ \\
\hline Pits $17-22$ & N/A & $\begin{array}{l}\text { Not } \\
\text { mapped }\end{array}$ & N/A & N/A & N/A & N/A & N/A & N/A & N/A & N/A & N/A \\
\hline Pit 23 & V4888 & $\begin{array}{l}\text { Pit } 23 \text { Tit } \\
\text { Hill Pit }\end{array}$ & $\begin{array}{l}\text { Pit 23- } \\
\text { Misidentified }\end{array}$ & $\begin{array}{l}\text { Tit Hill Pit - } \\
\text { Misidentifie } \\
\text { d }\end{array}$ & $\begin{array}{l}\text { Tit Hill } \\
\text { Pit } \\
\text { (Pit 23) }\end{array}$ & $\begin{array}{l}\text { Tit Hill Pit - } \\
\text { Misidentified }\end{array}$ & $\begin{array}{l}\text { Pit 23, Tit } \\
\text { Hill Pit, } \\
\text { Location } 13\end{array}$ & $\begin{array}{l}\text { Tit Hill Pit - } \\
\text { Misidentified }\end{array}$ & $\begin{array}{l}\text { Pit } 23 \\
\text { (Tit Hill Pit) }\end{array}$ & $\begin{array}{l}-71363.419 \mathrm{Y} \\
2880879.361 \mathrm{X}\end{array}$ & $\begin{array}{l}7120272.991 \mathrm{~N} \\
571334.874 \mathrm{E}\end{array}$ \\
\hline Tit Hill & V67270 & $\begin{array}{l}\text { Old } \\
\text { Dumps } \\
\text { Cooke } \\
1991 \\
\end{array}$ & Femur Dump & & N/A & Femur Dump & $\begin{array}{l}\text { Pit 23, Bolts } \\
\text { Farm } \\
\text { Dump, } \\
\text { Location } 13\end{array}$ & Femur Dump & Tit Hill & $\begin{array}{l}-71326.245 \mathrm{Y} \\
2880884.057 \mathrm{X}\end{array}$ & $\begin{array}{l}7120268.297 \mathrm{~N} \\
571297.715 \mathrm{E}\end{array}$ \\
\hline $\begin{array}{l}\text { Pit } 24 \\
\end{array}$ & N/A & N/A & N/A & N/A & N/A & N/A & $\mathrm{N} / \mathrm{A}$ & N/A & N/A & $\begin{array}{l}\text { No location data } \\
\text { made available }\end{array}$ & $\begin{array}{l}\text { No location } \\
\text { data made } \\
\text { available }\end{array}$ \\
\hline $\begin{array}{l}\text { Pit 25 } \\
\text { (Gazelle Pit) }\end{array}$ & V67267 & $\begin{array}{l}\text { Pit 25 } \\
\text { (Gazelle } \\
\text { Pit) }\end{array}$ & N/A & N/A & N/A & N/A & N/A & N/A & N/A & $\begin{array}{l}\text { No location data } \\
\text { made available }\end{array}$ & $\begin{array}{l}\text { No location } \\
\text { data made } \\
\text { available }\end{array}$ \\
\hline N/A & V67268 & N/A & N/A & N/A & N/A & N/A & New Cave & N/A & N/A & $\begin{array}{l}\text { No location data } \\
\text { made available }\end{array}$ & $\begin{array}{l}\text { No location } \\
\text { data made } \\
\text { available }\end{array}$ \\
\hline N/A & V67269 & N/A & N/A & N/A & N/A & N/A & Jackal Cave & N/A & N/A & $\begin{array}{l}\text { No location data } \\
\text { made available }\end{array}$ & $\begin{array}{l}\text { No location } \\
\text { data made } \\
\text { available }\end{array}$ \\
\hline
\end{tabular}


Table 2 (on next page)

Summary of localities discovered subsequent to UCAE mapping. GPS coordinates as first published and where possible, new accurate DGPS data. 
Table 2 Summary of localities discovered subsequent to UCAE mapping. GPS coordinates as first published and where possible, new accurate DGPS data.

1

\begin{tabular}{|c|c|c|c|}
\hline $\begin{array}{l}\text { New Locality } \\
\text { 1996-2016 }\end{array}$ & WGS 84 position and reference & $\begin{array}{l}\text { SA Hartebeesthoek 94/ Lo27 } \\
\text { (Edwards et al. 2018) }\end{array}$ & $\begin{array}{l}\text { UTM -35 Location } \\
\text { (Edwards et al. 2018) }\end{array}$ \\
\hline Waypoint 160 & $\begin{array}{l}\mathrm{S} 26^{\circ} 02^{\prime} 02.0^{\prime \prime} \mathrm{E} 27^{\circ} 42^{\prime} 50.0^{\prime \prime} \\
\text { (Sénégas et al., 2002) }\end{array}$ & $-71441.694 Y$ 2880778.398X & $\begin{array}{c}7120373.913 \mathrm{~N} \\
571413.117 \mathrm{E}\end{array}$ \\
\hline Brad Pit A and B & 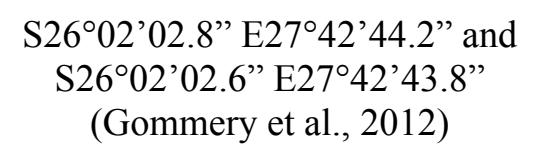 & $-71285.624 Y 2880805.139 X$ & $\begin{array}{l}7120347.183 \mathrm{~N} \\
571257.110 \mathrm{E}\end{array}$ \\
\hline U Cave & $\begin{array}{l}\mathrm{S} 26^{\circ} 1^{\prime} 49.20^{\prime \prime} \mathrm{E} 27^{\circ} 42^{\prime} 54.25^{\prime \prime} \\
\text { (Thackeray et al., 2008) }\end{array}$ & $\begin{array}{c}-71570.450 \mathrm{Y} \\
2880386.746 \mathrm{X}\end{array}$ & $\begin{array}{l}7120765.408 \mathrm{~N} \\
571541.822 \mathrm{E}\end{array}$ \\
\hline Brigitte Bones A & $\begin{array}{l}\text { S2601'57.4” E27 } 27^{\circ} 38.6^{\prime \prime} \\
\text { (Gommery et al., 2012) }\end{array}$ & Not located from provided coordinates & $\begin{array}{c}\text { Not located from provided } \\
\text { coordinates }\end{array}$ \\
\hline Brigitte Bones B & $\begin{array}{l}\text { S2601'57.6” E27 } 42^{\circ} 38.2^{\prime \prime} \\
\text { (Gommery et al., 2012) }\end{array}$ & Not located from provided coordinates & $\begin{array}{c}\text { Not located from provided } \\
\text { coordinates }\end{array}$ \\
\hline Alcephaline Site & $\begin{array}{l}\mathrm{S} 26^{\circ} 02^{\prime} 00.8^{\prime \prime} \mathrm{E} 27^{\circ} 42^{\prime} 49.0^{\prime \prime} \\
\text { (Sénégas et al., 2002) }\end{array}$ & $\begin{array}{c}-71428.251 \\
2880756.014\end{array}$ & $\begin{array}{l}7120393.54 \mathrm{~N} \\
571398.117 \mathrm{E}\end{array}$ \\
\hline Franky's Cave & $\begin{array}{l}\text { S26 } 6^{\circ} 01^{\prime} 44.6^{\prime \prime} \mathrm{E} 27^{\circ} 42^{\prime} 36.6^{\prime \prime} \\
\text { (Gommery et al., 2012) }\end{array}$ & $\begin{array}{c}-71087.901 \\
2880229.732\end{array}$ & $\begin{array}{c}7120922.934 \mathrm{~N} \\
571057.728 \mathrm{E}\end{array}$ \\
\hline Carnivore Pit & $\begin{array}{l}\text { S26 } 26^{\circ} 1^{\prime} 57.8^{\prime \prime} \mathrm{E} 27^{\circ} 42^{\prime} 39.1^{\prime \prime} \\
\text { (Gommery et al., 2012) }\end{array}$ & $\begin{array}{c}-71167.72 \\
2880654.998\end{array}$ & $\begin{array}{c}7120497.072 \mathrm{~N} \\
571140.817 \mathrm{E}\end{array}$ \\
\hline Dom's Site & $\begin{array}{l}\mathrm{S} 26^{\circ} 02^{\prime} 02.0 \mathrm{E} 27^{\circ} 42^{\prime} 48.8^{\prime \prime} \\
\text { (Thackeray et al., 2008) }\end{array}$ & $\begin{array}{c}-71413.037 \\
2880786.441\end{array}$ & $\begin{array}{l}7120366.659 \mathrm{~N} \\
571385.409 \mathrm{E}\end{array}$ \\
\hline Machine Cave & 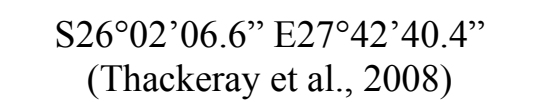 & $\begin{array}{c}-71191.354 \\
2880923.537\end{array}$ & $\begin{array}{l}7120228.221 \mathrm{~N} \\
571161.893 \mathrm{E}\end{array}$ \\
\hline
\end{tabular}




\section{Table 3(on next page)}

List of pits with maximum and minimum depositional ages as indicated by biochronologically informative species. 
1

Table 3: List of Pits with maximum and minimum depositional ages as indicated by biochronologically informative species.

\begin{tabular}{ccc}
\hline Pit Number & Max Age & Min Age \\
\hline Pit 1 & $<2.33 \mathrm{Ma}$ & 0.78 \\
Pit 2 & $\mathrm{NA}$ & NA \\
Pit 3 & $<2.33 \mathrm{Ma} / 1.89$ & 0.78 \\
Pit 4 & $\mathrm{Ma}$ & $\mathrm{NA}$ \\
Pit 5 & $<2.33 \mathrm{Ma}$ & $\mathrm{NA}$ \\
Pit 6 & $<2.33 \mathrm{Ma}$ & 0.78 \\
Pit 7 & $<2.33 \mathrm{Ma}$ & $\mathrm{Ma}(2.0 \mathrm{Ma})$ \\
Pit 8 & $4.4 \mathrm{Ma}$ & $\mathrm{NA}$ \\
Pit 10 & $\mathrm{NA}$ & $\mathrm{NA}$ \\
Milo A & $<3.7 \mathrm{Ma}$ & $>1.95$ \\
Pit 11 & $3.03-2.58$ & $\mathrm{NA}$ \\
Pit 14 & $<2 \mathrm{Ma}$ & $>1.95$ \\
Pit 15 & $3.03-2.58$ & $\mathrm{NA}$ \\
Pit 16 & $\mathrm{NA}$ & $0.99 \mathrm{Ma}$ \\
Pit 23 & $<2.33 \mathrm{Ma}$ & $>1.95$ \\
Pit 25 & $3.03-2.58$ & 0.78 \\
Jackal Cave & $<2.33 \mathrm{Ma}$ & $\mathrm{NA}$ \\
New Cave & $\mathrm{NA}$ & $\mathrm{NA}$ \\
Waypoint 160 & $<2.33 \mathrm{Ma}$ & $\mathrm{NA}$ \\
Brad Pit & $<5.0$ & $\mathrm{~N} / \mathrm{A}$ \\
\hline & $\mathrm{N} / \mathrm{A}$ &
\end{tabular}


Figure 1

Location of the Cradle in South Africa (left) and Bolt's Farm within the Cradle (right). Elevation data made available from Jarvis et al. 2008

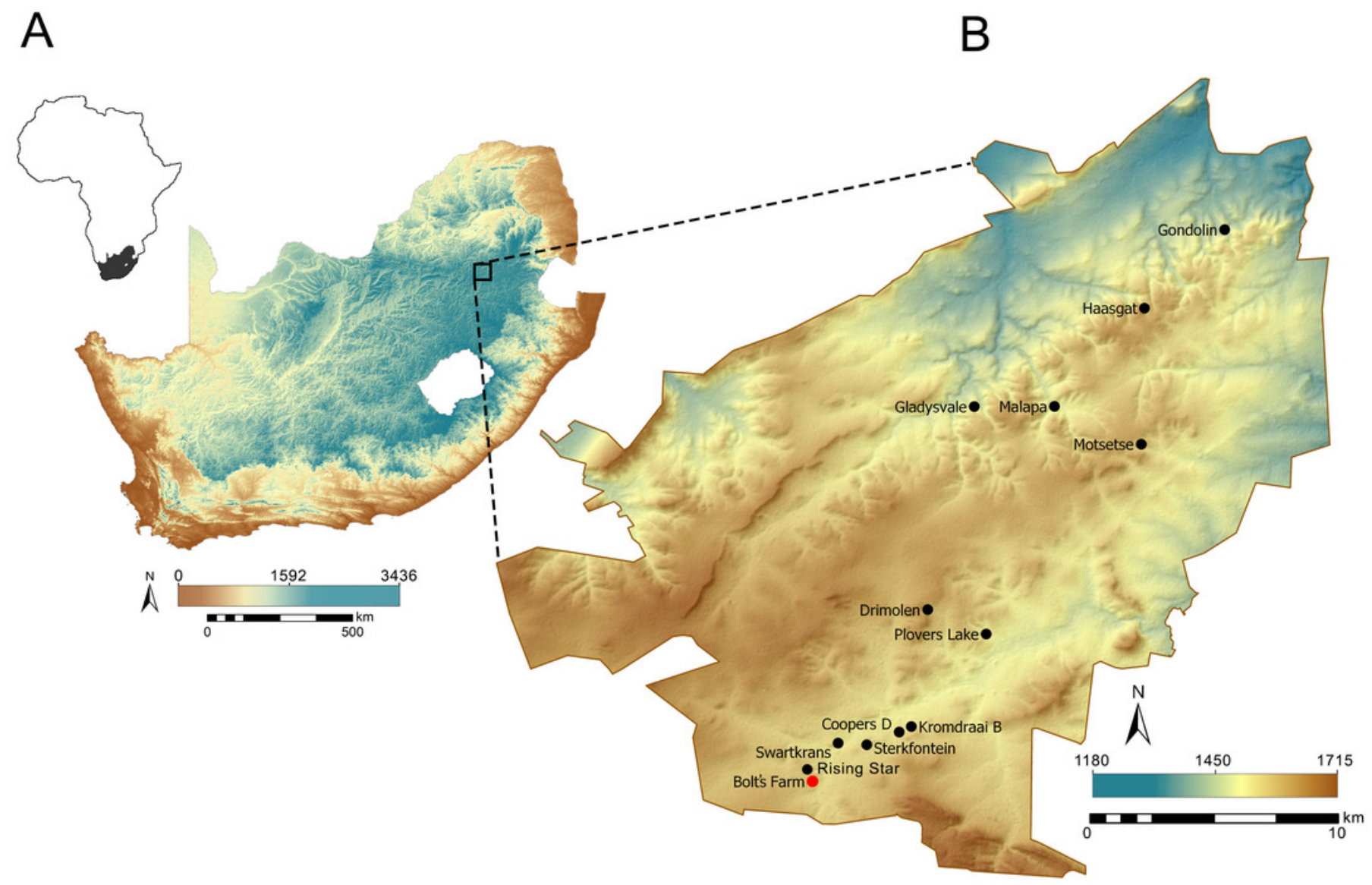


Figure 2

New georectified map of Bolt's Farm from accurate DGPS survey. Coordinate system WGS1984 UTM35S

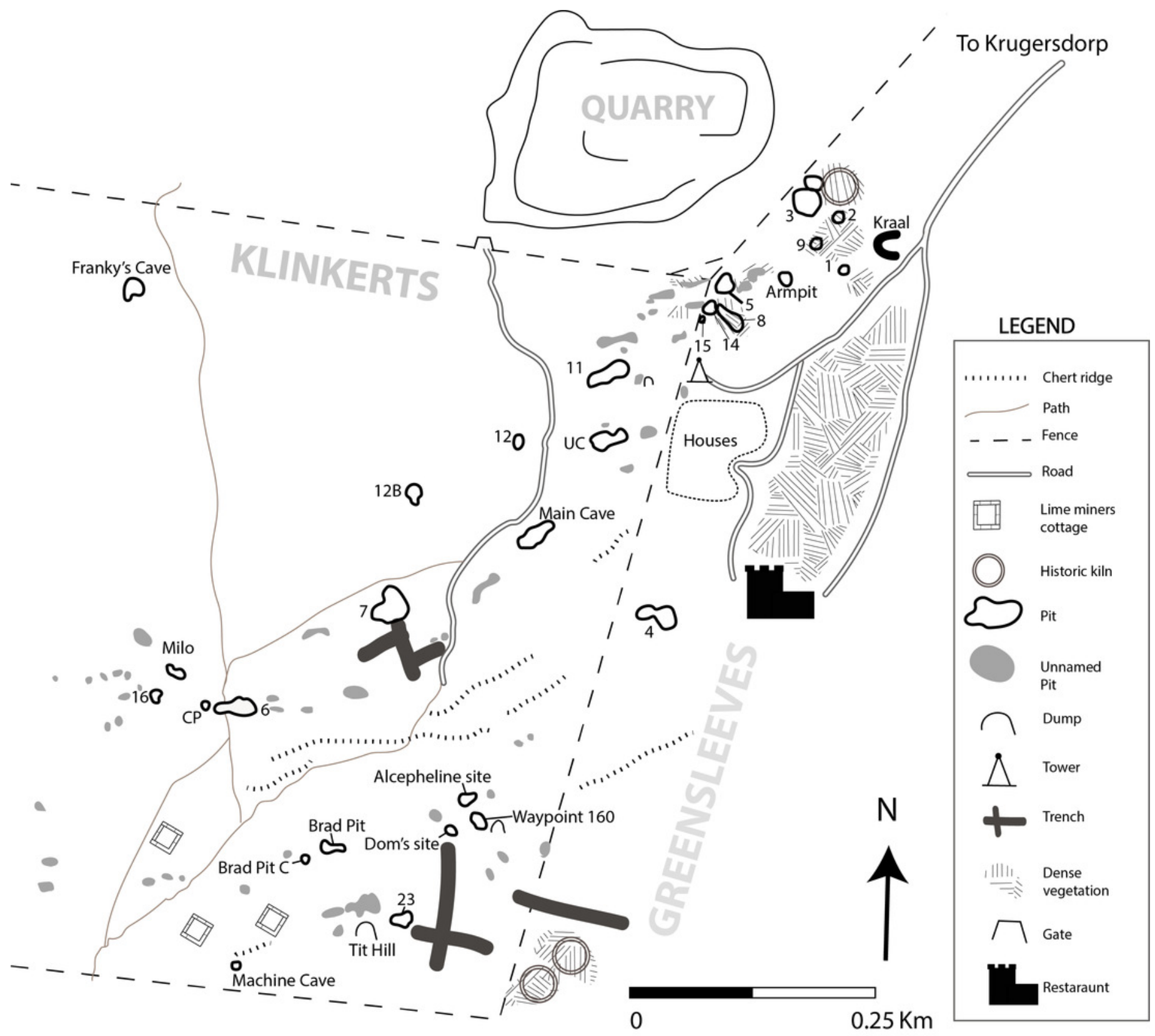


Figure 3

New map of Bolt's Farm with areas of pit location error highlighted A-D. Colours represent errors by source.

A) Errors pit locations in the 'Aves Cave Complex' including Pit5, 8, 13, 14, 15, Arm Pit. B)

Errors in location of PIt 11 and U Cave. C) Misidentification of Pit 23 D) Misidentification of Pit 16 as new site Milo $B$ and errors in the location of BBA and BBB
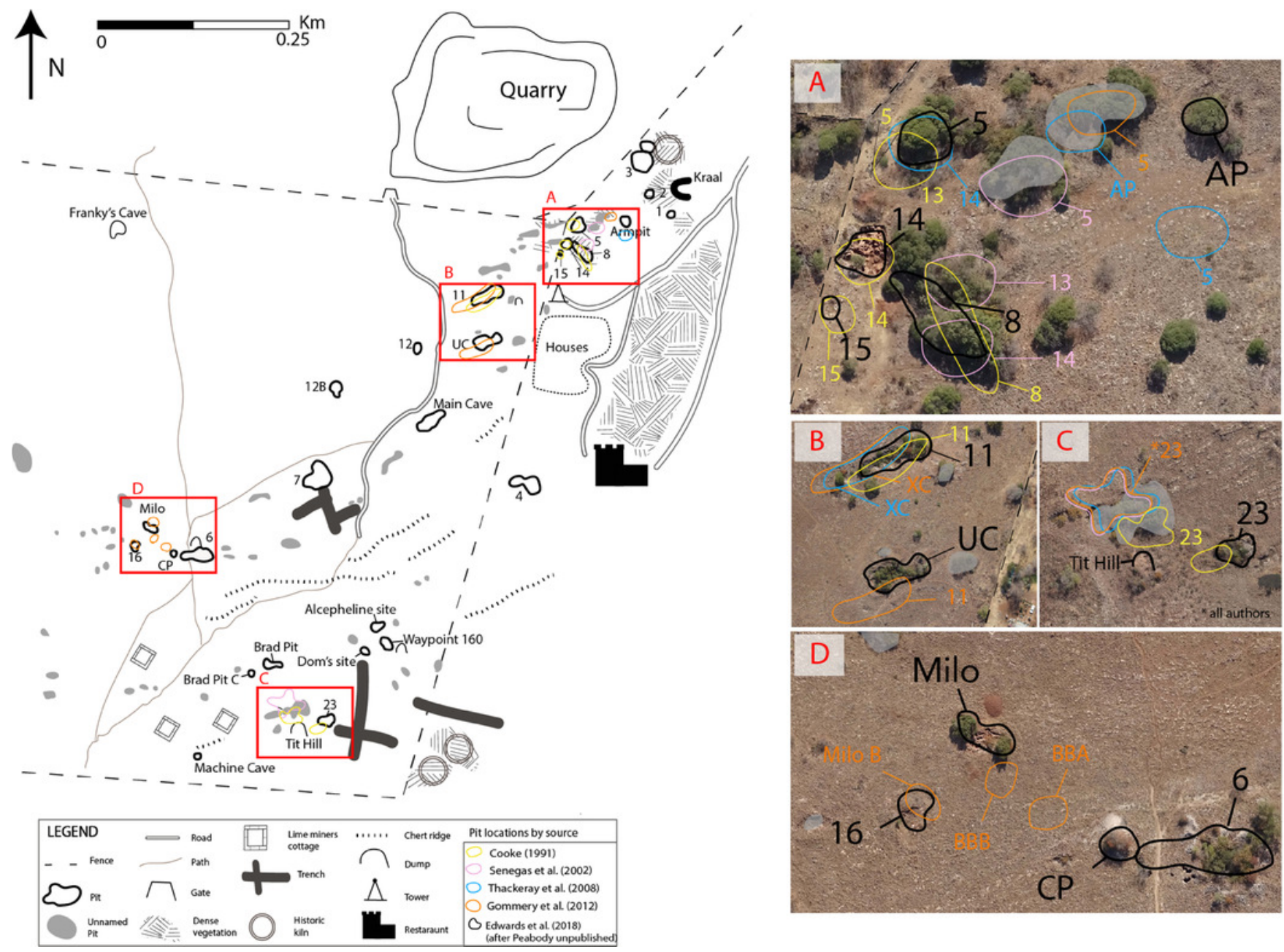